\title{
PENGARUH KEPEMIMPINAN TRANSFORMASIONAL DAN KOMPENSASI TERHADAP KEPUASAN KERJA MELALUI KOMITMEN ORGANISASI
}

\author{
Diansyah \\ Fakultas Ekonomi dan Bisnis Universitas 17 Agustus 1945 Jakarta \\ Email: diansyah.170845@yahoo.com
}

\begin{abstract}
Abstrak
Tujuan penelitian untuk mengetahui pengaruh kepemimpinan transformasional dan kompensasi terhadap kepuasan kerja melalui komitmen organisasi pada PT. Wira Mitra Prima. Metode pengumpulan data dengan menggunakan sensus sebanyak 39 orang sebagai populasi. Analisis data menggunakan Structural Equation Modeling-Partial Least Square (SEM-PLS) dengan menggunakan software SmartPLS versi 3. Tahapan perhitungan PLS menggunakan 2 model yaitu Pengukuran Model (Outer Model) dan Pengujian Model Struktural (Inner Model). Hasil penelitian menunjukkan bahwa kompensasi mempunyai pengaruh yang positif dan signifikan terhadap kepuasan kerja karyawan, kepemimpinan transformasional mempunyai pengaruh yang positif dan signifikan terhadap komitmen organisasi, kompensasi mempunyai pengaruh yang positif dan signifikan terhadap komitmen organisasi, komitmen organisasi mempunyai pengaruh yang positip dan signifikan terhadap kepuasan kerja karyawan, Selanjutnya kepemimpinan transformasional mempunyai pengaruh yang tidak signifikan terhadap kepuasan kerja karyawan, pengaruh kepemimpinan transformasional terhadap kepuasan kerja karyawan melalui komitmen organisasi adalah tidak signifikan begitu pula halnya pengaruh kompensasi terhadap kepuasan kerja karyawan melalui komitmen organisasi adalah juga tidak signifikan
\end{abstract}

Kata Kunci: Kepemimpinan Transformasional, Kompensasi, Kepuasan Kerja, Komitmen Organisasi

\begin{abstract}
The aim of research to determine the effect of transformational leadership and compensation to job satisfaction through organizational commitment at PT. Wira Mitra Prima. Data were collected by using the census as many as 39 people as a population. Methods of data analysis using Structural Equation Modeling-Partial Least Square (PLSSEM) with software version 3. Stages SmartPLS PLS calculation using the two models namely Measurement Model (Outer Model) and Testing Structural Model (Inner Model). The results showed that the compensation have positive influence and significant impact on employee satisfaction, transformational leadership has a positive influence and significant impact on organizational commitment, compensation has influence positively and significantly related to organizational commitment, organizational commitment has influence positively and significantly related to job satisfaction employee, then transformational leadership has no significant effect on employee job satisfaction, the influence of transformational leadership on employee satisfaction through organizational commitment is not significant so too is the influence of compensation on employee job satisfaction through organizational commitment is also not significant
\end{abstract}

Keywords: Transformational Leadership, Compensation, Job Satisfaction, Organizational Commitment 


\section{PENDAHULUAN}

Banyak industry jasa kiriman express, ekspedisi (delivery services), maupun freight forwarding (pengiriman kargo) pada saat ini masuk di jasa logistik terpadu (integrated logistics solution). Persaingan makin ketat dan tak hanya dengan sesama pelaku bisnis di dalam negeri tapi juga perusahaan luar negeri. (www.eksekutif.co.id, 24 Maret 2016).

Dengan persaingan begitu ketat pada industri tersebut, maka perusahaan berusaha memberikan pelayanan yang lebih baik agar kelangsungan perusahaan dapat terus terjaga. Untuk mempertahankan kelangsungan hidup perusahaan diperlukan kualitas karyawan yang baik dan kepuasan kerja karyawan terus diperhatikan dan ditingkatkan. Sumber daya manusia mempunyai potensi untuk terus berkembang dan menjadi lebih baik sangat penting perusahaan, maka karyawan dapat mengarahkan perusahaan untuk dapat mencapai kemajuan (Mira dan Margaretha, 2012). Menurut Suwardi dan Utomo (2012), kepuasan kerja karyawan memiliki peran sangat vital dalam rangka mendukung tercapainya tujuan perusahaan. Menurut Handoko (2010: 193) kepuasan kerja (job satisfaction) adalah keadaan emosional yang menyenangkan atau tidak menyenangkan dimana para karyawan memandang pekerjaan mereka. Kepuasan kerja mencerminkan perasaan seseorang terhadap pekerjaannya. Dalam kehidupan berorganisasi, kepuasan kerja digunakan untuk dasar ukuran tingkat kematangan organisasi. Salah satu gejala yang menyebabkan kurang baiknya kondisi kerja suatu organisasi adalah rendahnya kepuasan kerja. Sebaliknya kepuasan kerja yang tinggi merupakan kecenderungan efektivitas manajemen, yang berarti bahwa organisasi telah dikelola dengan baik.

Seperti halnya pada PT. Wira Mitra Prima merupakan perusahaan yang bergerak di bidang pelayanan jasa bongkar muat barang, petikemas dan pergudangan mengalami fenomena ketidakseimbangan masuk keluarnya container. Berdasarkan observasi di lapangan, beberapa karyawan PT. Wira Mitra Prima mengalami ketidakpuasan kerja misalnya kehadiran karyawan yang belum mencapai target minimal kehadiran $75 \%$ dalam satu semester semakin bertambah, tidak semua karyawan mendapat jaminan kesehatan, suasana kerja yang monoton dan gaya kepemimpinan yang kadang-kadang tidak sesuai keinginan karyawan.

Kepuasan kerja dipengaruhi banyak faktor yaitu kepemimpinan transformasional, kompensasi dan komitmen perusahaan. Menurut Lok dan Crawford (2004), salah satu faktor yang dapat mempengaruhi kepuasan kerja karyawan adalah kepemimpinan. Chang dan Lee (2007) mengemukakan bahwa kepemimpinan dapat mengatur perilaku karyawan dan dapat memprediksi kepuasan kerja karyawan. Chang dan Lee (2007) juga mengemukakan bahwa kepemimpinan yang dapat menentukan kepuasan kerja karyawan, salah satunya adalah kepemimpinan transformasional. Pandanganpandangan tersebut memberikan arah pemahaman bahwa kepemimpinan (khususnya kepemimpinan transformasional) dapat mempengaruhi kepuasan kerja karyawan, sehingga kepemimpinan beserta pengaruhnya terhadap kepuasan kerja karyawan perlu dilakukan dalam penelitian ini.

Kompensasi adalah bayaran yang diberikan perusahaan untuk dapat meningkatkan produktivitas para karyawan guna mencapai keunggulan yang kompetitif (Simamora, 2006). Dengan adanya kompensasi yang layak sesuai dengan kebutuhan dan keinginan karyawan maka karyawan bekerja dengan giat dan bekerja dengan sepenuh hati sehingga terciptanya kepuasan kerja karyawan.

Komitmen organisasi menyangkut kebanggaan karyawan terhadap pekerjaannya dan menjadi bagian dari organisasi sehingga dalam pelaksanaan tugas sebagai bagian dari organisasi. Karyawan memiliki 
komitmen untuk memberikan kontribusi terbaik bagi organisasi di samping itu karyawan yang mempunyai komitmen pada perusahaan (organisasi) mempunyai sikap atau loyalitas kepada organisasi dan ditandai dengan partisipasi pada organisasi sebagai titik focus dan berlanjut sampai organisasi mencapai sukses (Luthans, 2006). Komitmen organisasi akan menimbulkan rasa ikut memiliki terhadap organisasi karena karyawan memiliki kepuasan tersendiri berada pada organisasi tersebut. Seseorang yang berkomitmen kuat dalam dirinya akan tumbuh motivasi untuk mencapai suatu tujuan dan apabila pencapaian tujuan tersebut terpenuhi maka akan menimbulkan kepuasan kerja pada karyawan tersebut

Berdasarkan uraian dalam latar belakang masalah, maka permasalahan yang dirumuskan adalah sebagai berikut: Bagaimanakah pengaruh kepemimpinan transformasional dan kompensasi terhadap komitmen organisasi? Bagaimanakah pengaruh kepemimpinan transformasional dan kompensasi terhadap kepuasan kerja? Bagaimanakah pengaruh komitmen organisasi terhadap kepuasan kerja karyawan?

\section{REVIEW LITERATUR DAN PEMBENTUKAN HIPOTESIS}

Pengaruh Kepemimpinan Transformasional Terhadap Kepuasan Kerja

Pemimpin transformasional dapat memberikan keteladanan sebagai panutan bagi karyawannya, dapat mendorong karyawan untuk berperilaku kreatif, inovatif dan mampu memecahkan masalah dengan pendekatan baru. Selain itu, pemimpin transformasional juga peduli pada permasalahan yang dihadapi karyawan serta selalu memberikan motivasi agar dapat meningkatkan kinerja sehingga akan tercipta kepuasan kerja bagi para karyawannya. Dalam penelitian Pareke (2004) menemukan bahwa kepuasan kerja dipengaruhi oleh perilakuperilaku pemimpin transformasional. Pemimpin yang mempunyai kepemimpinan transformasional cenderung mempunyai tingkat kepuasan kerja yang tinggi. Dengan demikian kepemimpinan transformasional mempunyai pengaruh positip terhadap kepuasan kerja. Penelitian terdahulu yang mendukung mengenai kepemimpinan transformasional berpengaruh positif terhadap kepuasan kerja yaitu penelitian Setiago (2015), sehingga ditetapkan $\mathrm{H}_{1}$ dalam penelitian ini yaitu kepemimpinan transformasional berpengaruh positif terhadap kepuasan kerja .

\section{Pengaruh Kompensasi Terhadap Kepuasan Kerja}

Menurut Mondy (2008:4) kompensasi adalah jumlah seluruh imbalan yang didapat para karyawan sebagai subtitusi jasa yang telah mereka berikan. Pemberian kompensasi secara umum untuk menarik, mempertahankan dan memotivasi karyawan. Efek dari pemberian kompensasi oleh perusahaan memberikan dampak yang positif bila karyawan menerima kompensasi dirasa memuaskan hal ini dapat meningkatkan kepuasan kerja karyawan itu sendiri, dan sebaliknya pemberian kompensasi punya efek negatip apabila perusahaan tidak memberikan kompensasi yang layak bagi karyawan. Penelitian terdahulu yang mendukung mengenai kompensasi berpengaruh positif dan signifikan terhadap kepuasan kerja karyawan yaitu penelitian Putra (2011), Oktaviane (2013), Supiyanto (2015) dan Mufli (2015). Berdasarkan hasil-hasil penelitian terdahulu maka ditetapkan $\mathrm{H}_{2}$ dalam penelitian ini yaitu kompensasi berpengaruh positif terhadap kepuasan kerja karyawan.

\section{Pengaruh Kepemimpinan Trans- formasional Terhadap Komitmen Organisasi}

Kepemimpinan transformasional merupakan kemampuan pemimpin untuk memberikan inspirasi dan memotivasi para bawahannya untuk mencapai hasil yang direncanakan secara orisinil (Mondiani, 2012). Kepemimpinan transformasional yang baik akan berdampak pada karyawan 
untuk menjalankan peraturan perusahaan serta mempunyai komitmen organisasi untuk mengembangkan perusahaan, sehingga kepemimpinan transformasional mempunyai pengaruh yang positip terhadap komitmen organisasi. Penelitian terdahulu yang mendukung kepemimpinan transformasional berpengaruh positif dan signifikan terhadap komitmen organisasi yaitu penelitian Prasetyo (2008) dan Nurul, dkk. (2012). Berdasarkan hasil-hasil penelitian terdahulu maka ditetapkan $\mathrm{H}_{3}$ dalam penelitian ini yaitu kepemimpinan transformasional berpengaruh positif terhadap komitmen organisasi.

\section{Pengaruh Kompensasi Terhadap Komitmen Organisasi}

Menurut Simamora (2006:514) kompensasi adalah bayaran yang didapat karyawan yang diberikan perusahaan untuk meningkatkan produktivitas karyawan untuk mencapai keunggulan yang kompetitif. Semakin banyak karyawan yang diberi kompensasi yang layak dan adil berarti semakin karyawan lebih berkomitmen terhadap perusahaan. Dengan demikian kompensasi mempunyai pengaruh yang positip dan signifikan terhadap komitmen organisasi. Penelitian terdahulu yang mendukung mengenai kompensasi berpengaruh positif dan signifikan terhadap komitmen organisasi yaitu penelitian Supiyanto (2015) dan Apriyanti (2016). Berdasarkan hasil-hasil penelitian terdahulu maka ditetapkan $\mathrm{H}_{4}$ dalam penelitian ini yaitu kepemimpinan transformasional berpengaruh positif terhadap komitmen organisasi.

\section{Pengaruh Komitmen Organisasi terhadap Kepuasan Kerja}

Robbins (2008: 107) mengartikan bahwa kepuasan kerja adalah suatu sikap seseorang terhadap pekerjaan sebagai perbedaan antara jumlah ganjaran yang diterima karyawan dan jumlah yang seharusnya didapat. Dengan menunjukkan komitmen terhadap organisasi yang dijalankan maka adanya pengakuan sebagai karyawan oleh organisasi. Pengakuan karyawan oleh organisasi akan menimbulkan perasaan bangga dan mendorong kepuasan kerja yang tinggi. Dengan demikian komitmen organisasi mempunyai pengaruh positip dan signifikan terhadap kepuasan kerja. Penelitian yang terdahulu mendukung mengenai kompensasi berpengaruh positif dan signifikan terhadap komitmen organisasi yaitu penelitian Wahyuningrum (2009), Chandra (2013), Maesaroh (2015) dan Supriyanto (2015). Berdasarkan hasil-hasil penelitian terdahulu maka ditetapkan $\mathrm{H}_{5}$ dalam penelitian ini yaitu kepemimpinan transformasional berpengaruh positif terhadap komitmen organisasi.

\section{Pengaruh Kepemimpinan Trans- formasional Terhadap Kepuasan Kerja melalui Komitmen Organisasi}

Kepemimpinan transformasional adalah pemimpin yang mempunyai memahami keinginan dan kebutuhan bawahan akan meningkatkan, kepercayaan bawahan terhadap aktivitas organisasi, sehingga karyawan akan terinspirasi untuk melakukan pekerjaan sebaik mungkin. Semakin baik kepemimpinan transformasional menyebabkan meningkatnya pada komitmen organisasi pada karyawan yang selalu setia dan loyal kepada organisasi sehingga pada akhirnya kepuasan karyawan akan meningkat. Dengan demikian komitmen organisasi dapat berdampak nyata dan positip pada kepuasan kerja karyawan yang semakin meningkat. Demikian ada pengaruh yang positip dan signifikan kepemimpinan transformasional terhadap kepuasan kerja melalui komitmen organisasi. Penelitian terdahulu yang mendukung mengenai kepemimpinan transformasional berpengaruh positif dan signifikan terhadap kepuasan kerja melalui komitmen organisasi yaitu penelitian Mubarak dan Darmanto (2016). Berdasarkan hasil-hasil 
penelitian terdahulu maka ditetapkan $\mathrm{H}_{6}$ dalam penelitian ini yaitu kompensasi berpengaruh positif terhadap kepuasan kerja karyawan melalui komitmen organisasi

\section{Pengaruh Kompensasi Terhadap Kepuasan Kerja melalui Komitmen Organisasi}

Kompensasi adalah balas jasa yang diberikan oleh perusahaan kepada karyawan atas kontribusinya di dalam aktivitas perusahaan. Program kompensasi juga penting bagi perusahaan, hal itu mencerminkan upaya organisasi agar karyawan mempunyai loyalitas dan komitmen yang tinggi pada perusahaan (komitmen organisasi). Komitmen organisasi menyangkut kebanggaan karyawan terhadap pekerjaannya dan menjadi bagian dari organisasi sehingga dalam pelaksanaan tugas sebagai bagian dari organisasi. Semakin baik kompensasi yang diberikan karyawan oleh perusahaan menyebabkan peningkatan pada komitmen karyawan pada perusahaan yang selalu loyal kepada organisasi sehingga pada akhirnya kepuasan karyawan akan meningkat. Dengan demikian komitmen organisasi dapat memediasi atau sebagai perantara dan berdampak nyata dan positip pada kepuasan kerja karyawan yang semakin meningkat. Dengan demikian ada pengaruh yang positip dan signifikan kompensasi terhadap kepuasan kerja melalui komitmen organisasi. Penelitian terdahulu yang mendukung mengenai kompensasi berpengaruh positif dan signifikan terhadap kepuasan kerja melalui komitmen organisasi yaitu penelitian Mutiara (2004). Berdasarkan hasil-hasil penelitian terdahulu maka ditetapkan $\mathrm{H}_{7}$ dalam penelitian ini yaitu kompensasi berpengaruh positif terhadap kepuasan kerja karyawan melalui komitmen organisasi.

\section{METODE PENELITIAN Populasi dan Sampel}

Metode pengambilan data dengan menggunakan sensus sebanyak 39 orang sebagai populasi. Adapun populasi dan sekaligus dijadikan sampel akan diteliti dalam penelitian adalah seluruh karyawan tetap PT. Wira Mitra Prima sebanyak 39 orang.

\section{Metode Analisis Data}

Metode analisis data menggunakan Structural Equation Modeling-Partial Least Square (SEM-PLS) dengan menggunakan software SmartPLS versi 3. Tahapan perhitungan PLS menggunakan 2 model yaitu Model Pengukuran (Outer Model) dan Pengujian Model Struktural (Inner Model). Outer model adalah hubungan antara indikator dengan konstruknya. Bila nilai loading factor lebih dari 0,5 maka memiliki validitas yang baik. Uji signifikansi loading factor dapat dilakukan dengan t statistic atau $\mathrm{p}$ value, bila nilai $t$ statistik lebih dari 1,96 dan $p$ value $<0,05$ maka memiliki validitas signifikan. Analisis selanjutnya adalah reliabilitas konstruk dengan memperhatikan nilai Composite Reliability (CR), Cronbach's Alpha (CA) dan Average Variance Extracted (AVE). Bila nilai CR lebih dari 0,7, CA lebih dari 0,7 dan nilai AVE lebih dari 0,5 maka dikatakan konstruknya reliable (handal). Terakhir pengujian discriminant validity dari model pengukuran refleksif indikator, dengan cara membandingkan nilai akar AVE setiap konstruk dengan korelasi antara konstruk dengan konstruk lainnya dalam model (Ghozali, 2011).

Sebelum dilakukan pengujian model structural dilihat dulu $\mathrm{R}^{2}$ ( $\mathrm{R}$-Square) yaitu untuk menjelaskan kuat atau tidaknya konstruk. Chin (1998) mengelompokkan $\mathrm{R}^{2}$ ke dalam tiga kategori yaitu substansial $(0,67)$, moderat $(0,33)$ dan lemah $(0,19)$. Setelah model di estimasi memenuhi 
kriteria outer model maka selanjutnya dilakukan evaluasi atau pengujian model struktural (inner model). Inner model menggambarkan hubungan antar variabel laten berdasarkan pada teori substantive. Pengujian ini meliputi nilai signifikansi tiap koefisien jalur yang menyatakan ada pengaruh (signifikan) atau tidak ada pengaruh (non signifikan) antar konstruk memperhatikan nilai Path Coefficients. Pengujian model struktural digunakan untuk pengujian hipotesis antara variabel penelitian, dapat dilihat dari nilai $\mathrm{p}$ value dan $T$ statistic. Apabila nilai $T$ statistic $>$ 1,96 atau $p$ value $<0,05$ maka pengaruhnya signifikan (Ghozali, 2011).

\section{Operasionalisasi Variabel}

Berdasarkan perumusan masalah yang telah diuraikan sebelumnya, maka operasionalisasi variabel penelitian adalah seperti pada Tabel 1.

\section{Tabel 1. Operasionalisasi Variabel Penelitian}

\begin{tabular}{|c|c|c|}
\hline Variabel & Definisi Variabel & Indikator \\
\hline $\begin{array}{l}\text { Kepemimpinan } \\
\text { Transformasional } \\
\text { (X1) }\end{array}$ & $\begin{array}{l}\text { Kepemimpinan transformasional adalah } \\
\text { pemimpin yang karismatik dan } \\
\text { mempunyai peran sentral dan strategis } \\
\text { dalam membawa organisasi mencapai } \\
\text { tujuannya. }\end{array}$ & $\begin{array}{ll}\text { 1. } & \text { Karisma } \\
\text { 2. Motivasi Inspirasi } \\
\text { 3. Stimulasi Intelektual } \\
\text { 4. } & \text { Perhatian Individu }\end{array}$ \\
\hline $\begin{array}{l}\text { Kompensasi } \\
\text { (X2) }\end{array}$ & $\begin{array}{l}\text { Kompensasi adalah bentuk penghargaan } \\
\text { yang diberikan kepada karyawan sebagai } \\
\text { balas jasa atas kontribusi yang mereka } \\
\text { berikan kepada organisasinya. }\end{array}$ & $\begin{array}{l}\text { 1. Gaji } \\
\text { 2. Insentif } \\
\text { 3. Bonus } \\
\text { 4. Pelatihan dan } \\
\text { pengembangan } \\
\text { 5. Pujian } \\
\text { 6. Cuti }\end{array}$ \\
\hline $\begin{array}{l}\text { Kepuasan Kerja } \\
\text { (Y) }\end{array}$ & $\begin{array}{l}\text { Kepuasan kerjaadalah cerminan perasaan } \\
\text { seseorang terhadap pekerjaannya yang } \\
\text { dapat dilihat dari sikap karyawan terhadap } \\
\text { pekerjaan dan segala sesuatu yang ada di } \\
\text { lingkungan pekerjaannya. }\end{array}$ & $\begin{array}{l}\text { 1. Pekerjaan menantang } \\
\text { 2. Penghargaan sepadan } \\
\text { 3. Lingkungan kerja } \\
\text { 4. Rekan kerja } \\
\text { 5. Kesesuaian pekerjaan }\end{array}$ \\
\hline $\begin{array}{l}\text { Komitmen } \\
\text { Organisasi } \\
(\mathrm{Z})\end{array}$ & $\begin{array}{l}\text { Komitmen organisasi adalah kemampuan } \\
\text { dan kemauan untuk menyelaraskan } \\
\text { perilaku pribadi dengan kebutuhan, } \\
\text { prioritas dan tujuan organisasi } \\
\text { (perusahaan) yang meliputi cara-cara } \\
\text { mengembangkan tujuan atau memenuhi } \\
\text { kebutuhan organisasi yang intinya } \\
\text { mendahulukan misi organisasi dari pada } \\
\text { kepentingan pribadi. }\end{array}$ & $\begin{array}{ll}\text { 1. Komitmen Afektif } \\
\text { 2. Komitmen } \\
\text { Berkelanjutan } \\
\text { 3. Komitmen Normatif }\end{array}$ \\
\hline
\end{tabular}

\section{HASIL DAN PEMBAHASAN}

\section{Karakteristik Responden}

Jumlah responden dalam penelitian sebanyak 39 orang, dengan karakteristik dapat dilihat pada Tabel 2. Berdasarkan tabel tersebut diketahui jenis kelamin karyawan didominasi oleh pria sebanyak 37 orang (95\%), usia yang paling dominan 35-44 tahun sebanyak 19 orang (49\%), tingkat pendidikan yang paling dominan adalah SMA/STM sebanyak 24 orang (63\%), dan lamanya bekerja paling 
dominan 6-8 tahun sebanyak 14 orang $(38 \%)$.

\section{Tabel 2. Karakteristik Responden}

\begin{tabular}{lcc}
\hline Karakteristik Responden & f & \% \\
\hline Jenis Kelamin & & \\
$\quad$ Pria & 37 & 95 \\
$\quad$ Wanita & 2 & 5 \\
\hline Tingkat Pendidikan & & \\
$\quad$ SMP & 0 & 0 \\
SMA/STM & 24 & 63 \\
Akademi (D3) & 8 & 21 \\
$\quad$ Sarjana (S1 dan S2) & 7 & 16 \\
\hline Usia (Tahun) & & \\
$\quad$ 25 & 0 & 0 \\
$25-34$ & 15 & 38 \\
$35-44$ & 19 & 49 \\
$>44$ & 5 & 13 \\
\hline Lama Bekerja (Tahun) & 3 & 8 \\
$<3$ & 12 & 31 \\
$3-5$ & 14 & 38 \\
$6-8$ & 9 & 23 \\
$>8$ & & \\
\hline
\end{tabular}

\section{PLS Analysis}

Berdasarkan operasional variabel penelitian ini, dibentuk model penelitian yang kemudian di run menggunakan PLS Algorithm untuk menguji kelayakan model, digunakan outer model (model pengukuran) yaitu hubungan antara indikator dengan konstruknya. Untuk menguji validitas model dengan menggunakan nilai loading factor sedangkan untuk menguji reliabilitas menggunakan nilai Composite Reliability (CR), Cronbach's Alpha (CA) dan Average Variance Extracted (AVE).

Berdasarkan model awal, pengaruh kepemimpinan transformasional dan kompensasi terhadap kepuasan kerja karyawan, dengan komitmen organisasi sebagai variabel intervening, hasil perhitungan SmartPLS versi 3.6 dapat dilihat pada Gambar 1.

\section{Uji Validitas Konstruk}

Suatu indikator dinyatakan valid jika mempunyai loading factor $>0,5$. Nilai loading factor merupakan korelasi antara indikator dengan konstruknya (variabel).
Semakin tinggi korelasinya, semakin tinggi tingkat validitasnya dan juga menunjukan tingkat validitas yang lebih baik. Hasil perhitungan uji validitas dapat dilihat pada Tabel 3.

Berdasarkan Tabel 3 tersebut diketahui bahwa indikator X1P1 untuk konstruk Kepemimpinan Transformasional (X1) nilai loading faktornya $=0,660$, indikator X2P1 untuk Kompensasi (X2) nilai loading faktornya $=0,627$, indikator YP1 untuk konstruk Kepuasan Kerja Karyawan $(\mathrm{Y})=0,710$, indikator $\mathrm{ZP} 1$ untuk konstruk Komitmen Organisasi (Z) $=0,666$ dan seterusnya. Berdasarkan data tersebut diketahui setiap indikator mempunyai nilai loading factor lebih dari 0,5, ini artinya semua data valid.

\section{Uji Reliabilitas}

Analisis selanjutnya dari convergent validity adalah reliabilitas konstruk dengan memperhatikan nilai Composite Reliability (CR), Cronbach's Alpha (CA) dan Average Variance Extracted (AVE). Nilainilai Composite Reliability (CR), Cronbach's Alpha (CA) dan Average Variance Extracted (AVE) dapat dilihat pada Tabel 4.

Berdasarkan hasil perhitungan pada Tabel 4 diketahui semua nilai Composite Reliability > 0,7, Cronbach's Alpha > 0,7 dan Average Variance Extracted $>0,5$. Hasil ini menunjukkan seluruh konstruk memiliki validity yang baik dan konstruknya reliable (handal).

\section{Uji Validitas Diskriminan}

Pengujian ketiga dalam model pengukuran adalah discriminant validity (validitas diskriminan). Hasil perhitungan sebagaimana ditampilkan pada Tabel 5, diketahui akar AVE pada diagonal, lebih tinggi daripada korelasi antar konstruk lainnya pada kolom ke kiri dan ke bawah. Oleh karenanya dapat disimpulkan variabel penelitian memenuhi validitas diskriminan. 


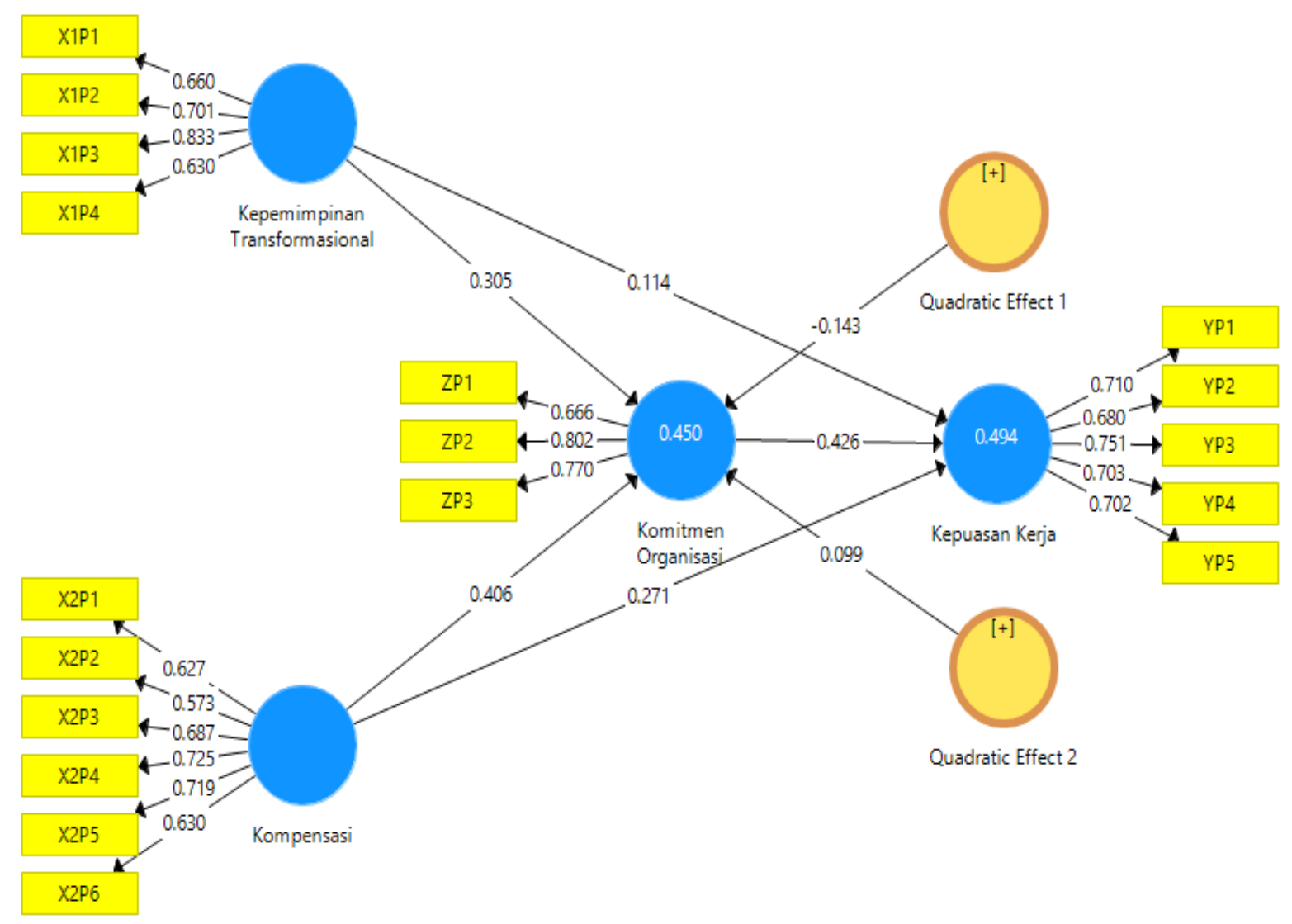

Gambar 1. Model Struktural

Sumber: Pengolahan data dengan PLS, 2016

Tabel 3. Outer Loading

\begin{tabular}{|c|c|c|c|c|c|}
\hline Konstruk dan Indikator & $\begin{array}{c}\text { Original Sample } \\
(\mathrm{O})\end{array}$ & $\begin{array}{c}\text { Sample Mean } \\
(M)\end{array}$ & $\begin{array}{c}\text { Standard Deviation } \\
\text { (STDEV) }\end{array}$ & $\begin{array}{l}\text { T Statistics } \\
(\mid \text { O/STDEV } \mid)\end{array}$ & P Values \\
\hline $\mathrm{X} 1 \mathrm{P} 1<-\mathrm{X} 1$ & 0,660 & 0,649 & 0,099 & 6,660 & 0,000 \\
\hline $\mathrm{X} 1 \mathrm{P} 2<-\mathrm{X} 1$ & 0,701 & 0,694 & 0,086 & 8,178 & 0,000 \\
\hline X1P3 <- X1 & 0,833 & 0,831 & 0,048 & 17,239 & 0,000 \\
\hline X1P4 <- X1 & 0,630 & 0,623 & 0,095 & 6,628 & 0,000 \\
\hline $\mathrm{X} 2 \mathrm{P} 1<-\mathrm{X} 2$ & 0,627 & 0,604 & 0,139 & 4.516 & 0,000 \\
\hline $\mathrm{X} 2 \mathrm{P} 2<-\mathrm{X} 2$ & 0,573 & 0,560 & 0,122 & 4,688 & 0,000 \\
\hline $\mathrm{X} 2 \mathrm{P3}<-\mathrm{X} 2$ & 0,687 & 0,694 & 0,066 & 10,380 & 0,000 \\
\hline $\mathrm{X} 2 \mathrm{P} 4<-\mathrm{X} 2$ & 0,725 & 0,720 & 0,067 & 10,861 & 0,000 \\
\hline X2P5 <- X2 & 0,719 & 0,714 & 0,070 & 10,727 & 0,000 \\
\hline X2P6<- X2 & 0,630 & 0,621 & 0,068 & 6,775 & 0,000 \\
\hline YP1 <- Y & 0,710 & 0,708 & 0,063 & 10,148 & 0,000 \\
\hline YP2 <- Y & 0,680 & 0,678 & 0,073 & 9,973 & 0,000 \\
\hline YP3 $<-$ Y & 0,751 & 0,749 & 0,075 & 11,927 & 0,000 \\
\hline YP4 <- Y & 0,703 & 0,693 & 0,092 & 9,675 & 0,000 \\
\hline YP5 <- Y & 0,702 & 0,696 & 0,050 & 9,403 & 0,000 \\
\hline $\mathrm{ZP1}<-\mathrm{Z}$ & 0,666 & 0,661 & 0,047 & 7,231 & 0,000 \\
\hline $\mathrm{ZP2}<-\mathrm{Z}$ & 0,802 & 0,800 & 0,041 & 15,881 & 0,000 \\
\hline ZP3 <- Z & 0,770 & 0,770 & 0,027 & 16,558 & 0,000 \\
\hline
\end{tabular}

Keterangan: X1 Kepemimpinan Transformasional, X2 Kompensasi, Y Kepuasan Kerja, Z Komitmen Organisasi 
Tabel 4. Nilai Composite Reliability, Cronbach's Alpha dan Average Variance Extracted

\begin{tabular}{cccc}
\hline \multirow{2}{*}{ Konstruk } & $\begin{array}{c}\text { Composite Reliability } \\
(\text { CR) }\end{array}$ & $\begin{array}{c}\text { Cronbach's Alpha } \\
\text { (CA) }\end{array}$ & $\begin{array}{c}\text { Average Variance } \\
\text { Extracted }\end{array}$ \\
\hline X1 & 0,801 & 0,772 & 0,504 \\
Y & 0,835 & 0,754 & 0,503 \\
Z & 0,791 & 0,707 & 0,560 \\
X2 & 0,824 & 0,746 & 0,539 \\
\hline
\end{tabular}

Keterangan: X1 Kepemimpinan Transformasional, X2 Kompensasi, Y Kepuasan Kerja, Z Komitmen Organisasi

Tabel 5. Hasil Validitas Diskriminan

\begin{tabular}{ccccc}
\hline Konstruk & X1 & $\mathbf{X 2}$ & Y & Z \\
\hline X1 & $\mathbf{0 . 7 0 7}$ & & & \\
X2 & 0.478 & $\mathbf{0 . 5 6 4}$ & & \\
Y & 0.437 & 0.479 & $\mathbf{0 . 7 4 8}$ & $\mathbf{0 . 7 5 8}$ \\
Z & 0.538 & 0.506 & 0.596 & .
\end{tabular}

Keterangan: X1 Kepemimpinan Transformasional, X2 Kompensasi, Y Kepuasan Kerja, Z Komitmen Organisasi Diagonal adalah akar dari AVE, sebelah kiri dan bawah adalah korelasi antar konstruk.

\section{Pengujian Hipotesis}

Untuk pembuktian hipotesis maka pengujiannya berdasarkan nilai Path Coefficients (Koefisien jalur) seperti Tabel 6.

Pembuktian Hipotesis H1 : Pengaruh Kepemimpinan Transformasional Terhadap Kepuasan Kerja Karyawan

Berdasarkan Tabel 6 menghasilkan nilai original sampel $=0,114$, $\mathrm{T}$ Statistik $=$ $0,720<1,96$ dan $\mathrm{P}$ Value $=0,472<0,05$. Hal ini berarti bahwa kepemimpinan transformasional mempunyai pengaruh yang positif dan tidak signifikan terhadap kepuasan kerja karyawan. Hasil penelitian ini tidak sesuai dengan penelitian dari Podsakoff dkk. (1996), Pareke (2004) dan Setiago (2015). Walaupun demikian ada penelitian terdahulu yang berlawanan dengan penelitian sebelumnya yaitu penelitian Permana (2010) Hal ini membuktikan bahwa hipotesis 1 ditolak. Ditolaknya hipotesis H1 dikarenakan kepemimpinan transformasional yang ada di PT. Wira Mitra Prima belum sepenuhnya memperhatikan karyawan secara individual (individual Consideartion) seperti perusahaan belum memberikan pekerjaan yang menantang bagi setiap karyawan yang menyukai tantangan sehingga pekerjaan yang dilakukan selalu monoton. Dengan demikian karyawan kurang bergairah dalam bekerja yang berakibat pada ketidakpuasan dalam bekerja.

\section{Pembuktian Hipotesis H2 : Pengaruh Kompensasi Terhadap Kepuasan Kerja Karyawan}

Berdasarkan tabel 12 menghasilkan nilai original sampel $=0,271, \mathrm{~T}$ Statistik $=$ 2,103>1,96 dan $\mathrm{P}$ Value $=0,036<0,05$. Hal ini berarti bahwa kompensasi mempunyai pengaruh yang positif dan signifikan terhadap kepuasan kerja. Hasil penelitian ini sesuai dengan penelitian dari Putra (2011), Oktaviane (2013), Supiyanto (2015) dan Mufli (2015). Hal ini membuktikan bahwa hipotesis 2 diterima.

Pembuktian Hipotesis H3 : Pengaruh Kepemimpinan Transformasional Terhadap Komitmen Organisasi

Berdasarkan tabel 12 menghasilkan nilai original sampel $=0,305$, $\mathrm{T}$ Statistik $=$ 2,810 $>1,96$ dan $\mathrm{P}$ Value $=0,005<0,05$. Hal ini berarti kepemimpinan transformasional mempunyai pengaruh yang positif dan signifikan terhadap komitmen organisasi. Hasil penelitian ini sesuai dengan penelitian dari Prasetyo (2008) dan Nurul dkk. (2012), hal ini membuktikan bahwa hipotesis 3 diterima. 
Pembuktian Hipotesis H4 : Pengaruh Kompensasi Terhadap Komitmen Organisasi

Berdasarkan tabel 12 menghasilkan nilai original sampel $=0,406$, $\mathrm{T}$ Statistik $=$ 4,140>1,96 dan $\mathrm{P}$ Value $=0,000<0,05$. Hal ini berarti bahwa kompensasi mempunyai pengaruh yang positif dan signifikan terhadap komitmen organisasi. Hasil penelitian ini sesuai dengan penelitian dari Apriyanti (2016) dan Supiyanto (2015). Hal ini membuktikan bahwa hipotesis 4 diterima.

\section{Pembuktian Hipotesis H5 : Pengaruh Komitmen Organisasi Terhadap Kepu- asan Kerja Karyawan}

Berdasarkan tabel 12 menghasilkan nilai original sampel $=0271$, $\mathrm{T}$ Statistik $=$ 2,103> 1,96 dan $\mathrm{P}$ Value $=0,036<0,05$. Hal ini berarti bahwa komitmen organisasimempunyai pengaruh yang negatif dan signifikan terhadap kepuasan kerja dan hasil penelitian ini sesuai dengan penelitian dari Wahyuningrum (2009), Chandra (2013), Maesaroh (2015) dan Supiyanto (2015). Hal ini membuktikan bahwa hipotesis 5 diterima.

\section{Pembuktian Hipotesis H6 : Pengaruh Kepemimpinan Transformasional Terhadap Kepuasan Kerja melalui Komitmen Organisasi}

Berdasarkan tabel 12 menghasilkan nilai original sampel $=-0,143$, $\mathrm{T}$ Statistik $=$ $1,624<1,96$ dan $\mathrm{P}$ Value $=0,105>0,05$. Hal ini berarti bahwa kepemimpinan transformasional mempunyai pengaruh negatip dan tidak signifikan terhadap kepuasan kerja melalui komitmen organisasi. Hasil penelitian ini tidak sesuai dengan penelitian dari Mubarak dan Darmanto (2016). Hal ini membuktikan bahwa hipotesis 6 ditolak. Ditolaknya hipotesis H6 dikarenakan kepemimpinan transformasional yang ada di PT. Wira Mitra Prima belum dapat menginspirasi bawahannya sehingga pimpinan belum bisa memotivasi karyawannya untuk mencapai tujuan bersama (inspiration motivation) seperti gaya kepemimpinan kadang-kadang tidak sesuai keinginan karyawan. Bila keinginan karyawan tidak terpenuhi maka komitmen organisasi yang menyangkut kebanggaan karyawan terhadap pekerjaan dan organisasinya akan menurun dan akibatnya akan menurunkan kepuasan kerja karyawan

\section{Pembuktian Hipotesis H7 : Pengaruh Kompensasi Terhadap Kepuasan Kerja melalui Komitmen Organisasi}

Berdasarkan tabel 12 menghasilkan nilai original sampel $=0,099, \mathrm{~T}$ Statistik $=$ $1,583<1,96$ dan $\mathrm{P}$ Value $=0,114>0,05$. Hal ini berarti bahwa kompensasi mempunyai pengaruh yang positip dan tidak signifikan terhadap kepuasan kerja melalui komitmen organisasi dan hasil penelitian ini tidak sesuai dengan penelitian dariMutiara (2004). Hal ini membuktikan bahwa hipotesis 7 ditolak. Ditolaknya hipotesis H7 dikarenakan perusahaan dalam memberikan kompensasi berupa jaminan kesehatan tidak semua karyawan mendapatkannya jaminan tersebut. Adanya perbedaan kompensasi yang tidak layak dan sesuai dengan kebutuhan dan keinginan karyawan maka karyawan tidak giat dan tidak sepenuh hati untuk bekerja, karyawan tidak merasa memiliki perusahaan dan memiliki komitmen organisasi yang rendah sehingga akan menurunkan kepuasan kerja.

\section{Koefisien Determinasi}

Sesuai dengan model pengukuran pengaruh kepemimpinan transformasional dan kompensasi terhadap kepuasan kerja karyawan dengan komitmen organisasi sebagai variabel interveningdapat dilihat pada Tabel 7. Berdasarkan tabel tersebut diketahui nilai konstruk kepuasan kerja karyawan $(\mathrm{Y})=0,494$. Hal mengandung makna bahwa pengaruh kepemimpinan transformasional(X1) dan kompensasi(X2) terhadap kepuasan kerja (Y) sebesar 49,4\% sedangkan sisanya 50,6\% dipengaruhi oleh faktor yang tidak diteliti dalam penelitian ini. Selanjutnya nilai konstruk komitmen 
organisasi $(Z)=0,450$. Hal mengandung makna bahwa pengaruh kepemimpinan transformasional (X1) dan kompensasi (X2) terhadap komitmen organisasi (Z) sebesar $45 \%$ sedangkan sisanya $55 \%$ dipengaruhi oleh faktor yang tidak diteliti dalam penelitian ini.

Tabel 6. Path Coefficients

\begin{tabular}{cccccc}
\hline & $\begin{array}{c}\text { Original } \\
\text { Sample }(\boldsymbol{O})\end{array}$ & $\begin{array}{c}\text { Sample } \\
\text { Mean }(\boldsymbol{M})\end{array}$ & $\begin{array}{c}\text { Standard Deviation } \\
(\text { STDEV })\end{array}$ & $\begin{array}{c}\text { T Statistics } \\
(\mid \text { O/STDEV })\end{array}$ & P Values \\
\hline X1 -> Y & 0,114 & 0,112 & 0,158 & 0,720 & 0,472 \\
X1 -> Z & 0,305 & 0,319 & 0,109 & 2,810 & 0,005 \\
Z ->Y & 0,426 & 0,422 & 0,141 & 3,027 & 0,003 \\
X2 ->Y & 0,271 & 0,280 & 0,129 & 2,103 & 0,036 \\
X2 -> Z & 0,406 & 0,422 & 0,098 & 4,140 & 0,000 \\
Quadratic Effect 1 -> Z & $-0,143$ & $-0,140$ & 0,088 & 1,624 & 0,105 \\
Quadratic Effect 2 -> Z & 0,099 & 0,090 & 0,063 & 1,583 & 0,114 \\
\hline
\end{tabular}

Sumber: Pengolahan data dengan PLS, 2016

Tabel 7. $R$ Square

\begin{tabular}{cccccc}
\hline & $\begin{array}{c}\text { Original Sample } \\
(\boldsymbol{O})\end{array}$ & $\begin{array}{c}\text { Sample Mean } \\
(\boldsymbol{M})\end{array}$ & $\begin{array}{c}\text { Standard Deviation } \\
(\text { STDEV })\end{array}$ & $\begin{array}{c}\text { T Statistics } \\
(\mid \text { O/STDEV } \mid)\end{array}$ & P Values \\
\hline $\mathrm{Y}$ & 0,494 & 0,532 & 0,082 & 6,049 & 0,000 \\
$\mathrm{Z}$ & 0,450 & 0,482 & 0,081 & 5,573 & 0,000 \\
\hline
\end{tabular}

Sumber: Pengolahan data dengan PLS, 2016

\section{PENUTUP}

Kesimpulan

1. Kepemimpinan transformasional mempunyai pengaruh yang positif dan tidak signifikan terhadap kepuasan.

2. Kompensasimempunyai pengaruh yang positif dan signifikan terhadap kepuasan kerja.

3. Kepemimpinan transformasional mempunyai pengaruh yang positif dan signifikan terhadap komitmen organisasi.

4. Kompensasi mempunyai pengaruh yang positif dan signifikan terhadap komitmen organisasi.

5. Komitmen organisasi mempunyai pengaruh yang positip dan signifikan terhadap kepuasan kerja.

6. Kepemimpinan transformasional mempunyai pengaruh yang negatip dan tidak signifikan terhadap kepuasan kerja.
7. Kompensasi mempunyai pengaruh yang positip dan tidak signifikan terhadap kepuasan kerja karyawan melalui komitmen.

\section{Saran}

1. Penelitian selanjutnya agar menambahkan variabel bebas selain kepemimpinan transformasional dan kompensasi.

2. Kepemimpinan transformasional belum sepenuhnya dilakukan oleh PT Wira Mitra Prima, sehingga pimpinan perusahaan dan pimpinan unit dapat menggerakan dan menginspirasi bawahannya agar lebih baik lagi untuk mencapai tujuan bersama. 


\section{DAFTAR PUSTAKA}

Apriyanti. (2016). Pengaruh Kompensasi Dan Kepuasan Kerja Terhadap Komitmen Pegawai PT. Lintang Sarana Media Malang, Jurnal JIBEKA. 10 (1), 10 - 13.

Anggraeni,Y., \& Santosa, T.E.C. (2013). Pengaruh Kepemimpinan Transformasional Terhadap Kepuasan Kerja Karyawan, Jurnal Dinamika Ekonomi \& Bisnis. 10(1).

Chandra, A.E. (2013). Pengaruh Komitmen Organisasi dan Kepemimpinan Terhadap Kepuasan Kerja dan Kinerja Karyawan PD. Wonoagung Sejahtera di Gresik, Tesis, Program Studi Magister Manajemen, Program Pascasarjana, Universitas Katolik Widya Mandala Surabaya.

Chang, S.C., \& Lee, M. S. (2007). A Study on Relationship Among Leadership, Organizational Culture, The Operation of Learning Organization and Employees' Job Satisfaction. The Learning Organization, 14(2), 155-185.

Daito, A. (2011). Pencarian Ilmu Melalui Pendekatan Ontologi, Epistemologi, Aksiologi, Edisi Pertama, Jakarta: Penerbit Mitra Wacana Media.

Ghozali, I. (2011), Struktural Equation Modeling Metode Alternatif dengan Partial Least Square. Semarang: Badan Penerbit Universitas Diponegoro.

Handoko, T.H. (2002). Manajemen Sumber Daya Manusia. Yogyakarta: Liberty.
Kaswara, L., \& Santoso, P. (2008). Analisa Faktor-Faktor Yang Mempengaruhi Komitmen Karyawan Terhadap Organisasi, Surabaya.

Kadarisman, M. (2012). Manajemen Pengembangan Sumber Daya Manusia. Depok: Rajagrafindo Persada.

Hasibuan, M.S.P. (2013). Manajemen Sumber Daya Manusia. Edisi Revisi. Jakarta: PT. Bumi Aksara.

Luthans, F. (2006). Organizational Behavior. New York: McGrawHill/Irwin.

Mira, W.S., \& Margaretha, M. (2012). Pengaruh Servant Leadership Terhadap Komitmen Organisasi dan Organization Citizenship Behavior. Jurnal Manajemen, 11(2), 99-116.

Mathis, R. L. \& Jackson, J.H. (2009). Human Resource Management. Jakarta: Salemba Empat.

Mobley, W. (1977) Intermediate Lingkage in the Relationship Between Satisfaction and Employee Turnover. Journal of Applied Psychology. 62(2), 237-240.

Mondy, W. (2008). Manajemen Sumber Daya Manusia, Jilid 2 Ed 10. Jakarta: Penerbit Erlangga, PT. Gelora Aksara Pratama.

Mondiani, T. (2012). Pengaruh Kepemimpinan Transformasional dan Kompensasi Terhadap Kinerja pegawai PT. PLN Persero UPJ Semarang. Jurnal Administrasi Bisnis. I(1).

Mufli, I.N. (2015). Pengaruh Kompensasi Dan Motivasi Kerja Terhadap Kepuasan Kerja Karyawan PT. Aseli Dagadu Djokdja, Skripsi, Fakultas Ekonomi Universitas Negeri Yogyakarta. 
Mubarak, A., \& Darmanto, S. (2016). Pengaruh Gaya Kepemimpinan Transformasional Dan Budaya Organisasi Terhadap Kinerja Pegawai Dengan Komitmen Organisasi Sebagai Variabel Intervening (Studi pada PNS di Kecamatan Watukumpul Kabupaten Pemalang). Maksimum. 5(1).

Mutiara. (2004). Komitmen Organisasi Sebagai Mediator Variabel Bagi Pengaruh Kepuasan Kerja Terhadap Turnover Intention Karyawan. Jurnal Bisnis dan Akuntansi. 6(1).

Maesaroh. (2015). Pengaruh Komitmen Dan Lingkungan Kerja Terhadap Kepuasan Kerja Dengan Motivasi Sebagai Variabel Intervening Pada Apotik Rumah Sakit Mitra Group Jakarta, Skripsi, Universitas 17 Agustus 1945 Jakarta.

Nurul, I. dkk. (2012). Pengaruh Keterlibatan Karyawan, Budaya Organisasi, dan Gaya Kepemimpinan terhadap Komitmen Organisasional dalam Meningkatkan Kinerja Karyawan (Studi pada Universitas Brawijaya). Jurnal Aplikasi Manajemen. 10(2).

Oktaviane, F. (2013). Pengaruh Kepemimpinan Dan Kompensasi Terhadap Kepuasan Kerja Karyawan PT. Pasoka Sumber Karya Padang, Skripsi, Fakultas Ekonomi Universitas Negeri Padang.

Pareke, F.Js. (2004). Kepemimpinan Transformasional dan Perilaku Kerja Bawahan: Sebuah Agenda Penelitian, Jurusan Manajemen Fakultas Ekonomi Universitas Bengkulu, Tidak Dipublikasikan.
Podsakoff, P., MacKenzie, S.B., \& Bommer, W.H., (1996). Transformational Leader Behavior and Substitutes for Leadership as Determinants of Employee Satisfaction, Commitment, Trust, and Organizational Citizenship Behaviors. Journal of Management, 22 (2), 259-298.

Permana, R.B. (2010). Pengaruh Gaya Kepemimpinan Transformasional, Budaya Organisasi Dan Learning Organization Terhadap kepuasan Kerja Karyawan Pada CV. Elresas Lamongan, Skripsi, Jurusan Manajemen Fakultas Ekonomi Universitas Pembangunan Nasional "Veteran" Jawa Timur

Putra, S. A. (2011). Pengaruh Kompensasi Dan Motivasi Terhadap Kepuasan Kerja Karyawan PT. Borwita Citra Prima di Sidoarjo, Skripsi, Fakultas Ekonomi Universitas Pembangunan Nasional "Veteran" Jawa Timur.

Prasetyo, A.J.H. (2008). Keterkaitan Antara Kepemimpinan Transformasional Dan Transaksional Dengan Komitmen Organisasional di PT. Kereta Api Indonesia (KAI) Stasiun Solo Balapan Surakarta, Tesis, Program Studi Magister Manajemen Universitas Sebelas Maret Surakarta

Robbins, S.P. (2009). Organizational Behavior. New Jersey: Prentices Hall.

Robbins, S., \& Timothy, A.J. (2008). Perilaku Organisasi, Organizational Behavior, Buku Terjemahan. Jakarta: Gramedia.

Rivai, V., et al. (2013). Manajemen Sumber Daya Manusia untuk Perusahaan. Jakarta: PT Raja Grafindo Persada. 
Robbin, S.P. (2003). Prinsip-Prinsip Perilaku Organisasi. edisi kelima, Jakarta: Erlangga.

Samsudin, S. (2006). Manajemen Sumber Daya Manusia Cetakan ke-1. Bandung: Penerbit CV Pustaka Setia.

Simamora, H. (2006). Manajemen Sumber Daya Manusia. Edisi 3. Cetakan Kedua. Yogyakarta: STIE YKPN.

Simamora, H. (2004). Manajemen Sumber Daya Manusia, Yogyakarta: STIE YKPN.

Silalahi, B.Y. (2008). Kepemimpinan Transformasional , Motivasi Kerja, Budaya Organisasi dan Komitmen Organisasi, Jurnal Psikologi, 2(1).

Soekidjan, S. (2009). Komitmen Organisasi Sudahkah Menjadi Bagian Dari Kita. Diakses tanggal 1 Maret 8 Maret:www.kesad.mil.id/ category/berita/ditkesad.

Sugiyono. (2012). Metode Analisi Data Dengan Pengumpulan Data Responden. Bandung: Alfabeta.

------- (2014). Metode Penlitian Kualitatif dan Kuantitatif. Bandung: Alfabeta (2013). Metode Penelitian Pendidikan. Bandung: Alfabeta

Sutrisno, E. (2013). Manajemen Sumber Daya Manusia. Bandung: Alfa Beta.

Utomo, K.W. (2002). Kecenderungan Kepemimpinan Transaksional Dan Transformasional, dan Hubungannya Dengan Organizational Citizenship Behavior, Komitmen Organisasi, dan Kepuasan Kerja. Journal Riset Ekonomi dan Manajemen. 2(2), 34-52.

Sopiah. (2008). Perilaku Organisasi. Yogyakarta: Andi.
Supiyanto, Y. (2015). Pengaruh Kompensasi, Kompetensi dan Komitmen Organisasional Terhadap Kepuasan Dan Kinerja, Jurnal Economia, 11(2).

Setiago, W.V. (2015). Pengaruh Kepemimpinan Transformasional Terhadap Kepuasan Kerja Dengan Perceived Organizational Support Sebagai Variabel Mediasi Di Restoran Platinum Grill. Jurnal Hospitality Dan Manajemen Jasa. 3(2).

Suwardi \& Utomo, J. (2012). Pengaruh Motivasi Kerja, Kepuasan Kerja, dan Komitmen Organisasional Terhadap Kinerja Pegawai (Studi Pada Pegawai Setda Kabupaten Pati). Analisis Manajemen, 5(1): 75-86.

Wahyuningrum, C.H. (2009). Pengaruh Komitmen Profesional dan Komitmen Organisasi Terhadap Kepuasan Kerja Auditor : Motivasi Sebagai Variabel Intervening ( Studi Empiris Pada Kantor Akuntan Publik di Semarang. Skripsi. Fakultas Ekonomi, Universitas Negeri Semarang.

www.eksekutif.co.id, diakses tanggal 24 Maret 2014.

Yukl, G.A,. (2009). Leadership in Organization, Second Edition. New Jersey: Englewood Clifs, PrenticeHall, Inc. 